\title{
Age-related macular degeneration: an overview
}

\author{
Degeneração macular relacionada à idade: um panorama geral
}

Rogil José de Almeida Torres $^{1}$ (D), Ana Lúcia dos Anjos Ferreira ${ }^{1}$ (1)

Keywords:

Macular degeneration; Oxidative stress; Inflammation;

Retinal pigment epithelium; Biomarkers; Primary prevention;

Secondary prevention

Descritores:

Degeneração macular; Estresse oxidativo; Inflamação; Epitélio pigmentado da retina;

Biomarcadores; Prevenção primária; Prevenção secundária

Received on: Mar 20, 2021

Accepted on: Jun 25, 2021

Corresponding author: Rogil José de Almeida Torres Rua Emiliano Perneta, 390, Conj. 1407. Curitiba-PR. CEP 80420-080 E-mail rjat0713@gmail.com

Institution: Universidade Estadual Paulista "Júlio de Mesquita Filho", Botucatu, SP, Brazil.

Conflict of interest: no conflict of interest.

Financial support: the authors received no financial support for this work.

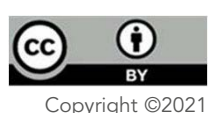

Copyright (C)2021

\section{ABSTRACT}

Age-related macular degeneration is the most important cause of irreversible vision loss in the elderly and has been considered a severe public health problem. Current treatments have only been successful in delaying the loss of central vision. Due to increased life expectancy, governments and researchers have been challenged to seek more efficient and successful treatments for age-related macular degeneration. Considering its relevance for public health and the need of further research, this article aims to address age-related macular degeneration objectively, tackling on the current knowledge about its pathophysiology, potential molecular biomarkers, main prevention procedures and treatments, as well as introducing possible molecules that may be a therapeutic target in this disease.

\section{RESUMO}

Degeneração macular relacionada à idade é a causa mais importante de perda irreversível da visão em idosos, e é considerada um sério problema de saúde pública. Os tratamentos atuais são bem-sucedidos apenas ao postergar a perda da visão central. Devido à maior expectativa de vida, os governos e pesquisadores têm dificuldade de encontrar tratamentos mais eficientes e exitosos para degeneração macular relacionada à idade. Considerando sua relevância para saúde pública e a necessidade de mais pesquisas, este artigo procura abordar a degeneração macular relacionada à idade de forma objetiva, abordando os conhecimentos atuais sobre sua fisiopatologia, potenciais biomarcadores moleculares, principais procedimentos de prevenção e tratamentos, e apresentar possíveis moléculas que podem ser alvo terapêutico nessa doença. 


\section{LITERATURE SEARCH METHODS}

Aiming to address age-related macular degeneration pathophysiology, use of possible biomarkers, as well as its prevention and treatment, a comprehensive literature review was performed through Cochrane Database, PubMed, MedlinePlus Health Information, and Elsevier Science. We used the following keywords and their synonyms in various combinations: age-related macular degeneration, oxidative stress, chronic inflammation, retinal pigment epithelium, biomarkers, primary prevention, secondary prevention, therapy. Articles cited in the reference list of publications obtained through this search were also reviewed, whenever relevant.

\section{INTRODUCTION}

Age-related macular degeneration (AMD) is one of the main causes of irreversible vision loss in the elderly. ${ }^{(1)}$ It is a complex, multifactorial disease, associated with aging, and genetic, nutritional, and environmental alterations. ${ }^{(2)}$ Due to the highly impactful nature of this disease, several studies have correlated it with depression, recommending immediate need of psychological support. (3,4)

\section{AGE-RELATED MACULAR DEGENERA- TION PATHOPHYSIOLOGICAL MECHA- NISMS}

The macula region of the retina is responsible for visual acuity and color vision, and it is a place where all light beams converge to form an image. It is exposed to a high concentration of oxygen, polyunsaturated fatty acid content, high incidence of light rays (between $400 \mathrm{~nm}$ and $700 \mathrm{~nm}$ ), and has photosensitive molecules, such as rhodopsin and lipofuscin. These characteristics induce a continuous production of oxygen reactive species (ROS). (5) Conversely, the sensory retina and retinal pigment epithelium (RPE) cells present an antioxidant machinery coordinated by the nuclear factor erythroid 2-related factor 2 (Nrf-2), which neutralizes the physiologically or pathologically originated $\mathrm{ROS}_{,}{ }^{(6)}$ maintaining proteostasis. ${ }^{(7)}$ With aging, oxidative damage gradually increases since the antioxidant capacity decreases concurrently in mammals. As a result, the inherent repair capacity of RPE cells becomes compromised. ${ }^{(8-10)}$ This resultant redox imbalance plays an important role in triggering and progression of $\mathrm{AMD}^{(11)}$ inducing the accumulation of lipofuscins in the RPE cells, decreasing their function, ${ }^{(12-14)}$ and increasing oxidative stress and retinal inflammation. ${ }^{(15,16)}$ The dysfunction of RPE cells, on its turn, leads to failure in degradation of products resulting from phagocytosis of the photoreceptor cell outer segments, causing pathological accumulation of lipids in the Bruch's membrane (BM). ${ }^{(17)}$ The low-density lipoproteins (LDL) undergo oxidation, making the endothelial and RPE cells increase the expression of vascular adhesion molecules (P-selectin, intercellular adhesion molecule 1 and vascular cell adhesion molecule 1), interleukin 8 (IL-8), which, along with the monocyte chemoattractant protein-1 ligands (MCP1) and their $C-C$ chemokine receptors type 2 (CCR2), improve activation and recruitment of monocytes to phagocytize oxidized LDL. . $^{(18-20)}$ The macrophages, as well as the endothelial and RPE activated cells, induce an increased expression of cytokines, enzymes, and growth factors, closely related to progression of the macular degenerative disease. ${ }^{(21-23)}$ Simultaneously, alterations in the BM interfere in the RPE cell nutrition, causing RPE and choriocapillaris atrophy, ${ }^{(24-26)}$ and consequently triggering the choroid geographic atrophy. The reduction in choriocapillaris layer leads to hypoxia and resulting death of the photoreceptors, and major damage to RPE cells. ${ }^{(27)}$ Hypoxia induces release of vascular endothelial growth factor (VEGF) ${ }^{(28)}$ and develops subretinal neovascularization, ${ }^{(2)}$ hence, typifying wet AMD.

\section{POTENTIAL MOLECULAR BIOMARKERS}

Considering the several molecules involved in AMD genesis, important studies have been performed aiming to validate biomarkers that may provide prediction, diagnosis, stratification, monitoring of treatment, and drug development for AMD. The most promising biomarkers belong to the oxidative stress pathway, the complement system, and to a lesser extent, to lipid metabolism. Many studies reported decreased antioxidant levels and elevated levels of oxidized proteins or lipids indicating oxidative stress in AMD. Malondialdehyde, a marker for lipid peroxidation, homocysteine, an intermediate in the oxidative stress pathway, and the involvement of the complement system have provided more consistent results as AMD biomarkers. ${ }^{(29)}$ Nevertheless, a variety of differences between studies, including methodological differences (fasting versus non-fasting blood), different populations (Caucasian/ Asian/Mediterranean) with diverse dietary habits, different study designs, different analytical methods, and correction factors offer contradicting, difficult-to-interpret results, suggesting the need for large well-conducted prospective studies to further clarify these findings. Additionally, because of the presence of the blood-retinal barrier, biomarkers might be only locally dysregulated inside the eye with no measurable systemic effect. ${ }^{(29)}$ Other 
biomarker types in AMD, such as genetic factors, imaging biomarkers, or visual function measurements, are currently of key importance for proper clinical diagnosis, stratification, and treatment of AMD. ${ }^{(29)}$

\section{PREVENTION}

From a preventive perspective, healthy diet, regular physical activities, wear of glasses with filters that protect against harmful rays present in the visible light, even oral hygiene, have been recommended to prevent the onset and/or progression of AMD. ${ }^{(30-35)}$ Nevertheless, the main modifiable factor for AMD is smoking, and quitting smoking is highly recommended. ${ }^{(36,37)}$ Regarding the use of synthetic antioxidants, it has been demonstrated they are not effective for prevention of primary AMD; that is, they do not prevent drusen or pigmental alterations in the macular region, reported to be the first manifestations of the disease. ${ }^{(38)}$ Nevertheless, in secondary prevention, when the disease has already developed, the Age-Related Eye Disease Study (AREDS) has concluded that (a) without nutritional supplements, patients with intermediate AMD had an $18 \%$ chance of progressing to advanced AMD, in one or both eyes, over 5 years; (b) without nutritional supplements, patients with advanced AMD in one eye had a $43 \%$ chance of progressing to advanced AMD in the other eye; (c) with nutritional supplements, high-risk patients decreased their risk of progressing to AMD by $25 \%$ (in the case of advanced AMD in one eye, this decreased risk refers to the other eye); (d) with nutritional supplements, risk of moderate or severe vision loss decreased by $19 \%$, over 5 years; (e) nutritional supplements did not slow progression from early AMD to intermediate AMD; (f) there was no evidence that vision loss or disease progression was reversed in any treatment group; (g) compared to placebo, addition of lutein/zeaxanthin and/or omega-3 fatty acids to the previous AREDS formulation showed no significant effect on AMD progression or visual acuity loss. The adopted nutritional supplementation formula included a dose of $500 \mathrm{mg}$ of Vitamin C, 400 IU of vitamin E, $10 \mathrm{mg}$ of lutein, $2 \mathrm{mg}$ of zeaxanthin, $80 \mathrm{mg}$ of zinc and $2 \mathrm{mg}$ of copper. ${ }^{(39)}$

\section{TREATMENT}

In the treatment of advanced AMD, with the geographic atrophy of the choroid, blocking complement activation reduced its rate by $29 \% .{ }^{(40)}$ Other approaches, such as the cell-based therapy, have also been considered. ${ }^{(41,42)}$ Regarding wet-AMD, the treatment with anti-VEGF was revolutionary, enabling vision preservation in many patients. ${ }^{(43)}$ However, the need of periodic interventions, discomfort and high cost make this treatment still not available to most people. ${ }^{(44)}$

\section{CONCLUSION}

A more comprehensive understanding of AMD pathophysiology in the last decades has been of outmost importance in the quest for new treatments. ${ }^{(2)}$ Changes in lifestyles have been reported as one of the major factors in longevity and vision preservation. ${ }^{(45)}$ The nutritional supplementation is of great importance in cases of intermediate AMD. ${ }^{\left({ }^{9}\right)}$ The malondialdehyde biomarkers, homocysteine and the complement system are potential aids in prediction, diagnosis, stratification, monitoring of treatment, and drug development for AMD. Local inhibition of complement activation has been considered a promising approach for treatment of both forms of late AMD. In light of the probable role of complement system in the development of AMD, many clinical trials investigating the effect of complement inhibitors have been conducted or are in progress. The results of clinical trials, in which often only a subgroup of patients responded favorably, have shown careful stratification of indications and patient cohorts will be critical to identify patients who may benefit from complement-mediated therapies. ${ }^{(46)}$ Overly complex molecular mechanisms found in the endothelial and in RPE cells, in microglia of the sensory retina and in macrophages, such as the Nrf2, ${ }^{(6)}$ nuclear factor kappa $\beta$ (NF- $\kappa \beta),{ }^{(15)}$ inflammasome, ${ }^{(47)} \mathrm{NADPH}$-oxidase (NOX), ${ }^{(15)}$ complement system, ${ }^{(40,48)}$ among others, are likely to become future therapeutic approaches, improving prognosis of AMD.

\section{REFERENCES}

1. Friedman DS, O'Colmain BJ, Muñoz B, Tomany SC, McCarty C, de Jong PT, et al. Eye Diseases Prevalence Research Group. Prevalence of age-related macular degeneration in the United States. Arch Ophthalmol. 2004;122(4):564-72.

2. Ambati J, Ambati BK, Yoo SH, lanchulev S, Adamis AP. Age-related macular degeneration: etiology, pathogenesis, and therapeutic strategies. Surv Ophthalmol. 2003;48(3):257-93.

3. Brody BL, Gamst AC, Williams RA, Smith AR, Lau PW, Dolnak D, et al. Depression, visual acuity, comorbidity, and disability associated with agerelated macular degeneration. Ophthalmology. 2001;108(10):1893-900.

4. Mathew RS, Delbaere K, Lord SR, Beaumont P, Vaegan, Madigan MC Depressive symptoms and quality of life in people with age- related macular degeneration. Ophthalmic Physiol Opt. 2011;31(4):375-80.

5. Beatty $\mathrm{S}$, Koh $\mathrm{H}$, Phil M, Henson D, Boulton M. The role of oxidative stress in the pathogenesis of age-related macular degeneration. Surv Ophthalmol. 2000;45(2):115-34

6. Bellezza I. Oxidative Stress in Age-Related Macular Degeneration: Nrf2 as Therapeutic Target. Front Pharmacol. 2018;9:1280.

7. Pajares M, Jiménez-Moreno N, García-Yagüe ÁJ, Escoll M, de Ceballos ML, Van Leuven F, et al. Transcription factor NFE2L2/NRF2 is a regulator of macroautophagy genes. Autophagy. 2016;12(10):1902-16. 
8. Dröge W. Aging-related changes in the thiol/disulfide redox state: implications for the use of thiol antioxidants. Exp Gerontol. 2002;37(12):1333-45.

9. Dröge W. Free radicals in the physiological control of cell function. Physiol Rev. 2002;82(1):47-95.

10. Frank RN, Amin RH, Puklin JE. Antioxidant enzymes in the macular retinal pigment epithelium of eyes with neovascular age-related macular degeneration. Am J Ophthalmol. 1999;127(6):694-709.

11. Evereklioglu C, Er H, Doganay S, Cekmen M, Turkoz Y, Otlu B, et al. Nitric oxide and lipid peroxidation are increased and associated with decreased antioxidant enzyme activities in patients with age-related macular degeneration. Doc Ophthalmol. 2003;106(2):129-36.

12. Kaarniranta K, Sinha D, Blasiak J, Kauppinen A, Veréb Z, Salminen A, et al. Autophagy and heterophagy dysregulation leads to retinal pigment epithelium dysfunction and development of age-related macular degeneration. Autophagy. 2013;9(7):973-84

13. Ferrington DA, Sinha D, Kaarniranta K. Defects in retinal pigment epithelial cell proteolysis and the pathology associated with age-related macular degeneration. Prog Retin Eye Res. 2016;51:69-89.

14. Watzke RC, Soldevilla JD, Trune DR. Morphometric analysis of human retinal pigment epithelium: correlation with age and location. Curr Eye Res. 1993;12:133-42.

15. Wang H, Fotheringham L, Wittchen ES, Hartnett ME. Rap1 GTPase Inhibits Tumor Necrosis Factor- $\alpha$-Induced Choroidal Endothelial Migration via NADPH Oxidase- and NF-KB-Dependent Activation of Rac1. Am J Pathol. 2015;185(12):3316-25.

16. Karlstetter M, Ebert S, Langmann T. Microglia in the healthy and degenerating retina: insights from novel mouse models. Immunobiology. 2010;215(9-10):685-91.

17. Ruberti JW, Curcio CA, Millican CL, Menco BP, Huang JD, Johnson M. Quick-freeze/deep-etch visualization of age-related lipid accumulation in Bruch's membrane. Invest Ophthalmol Vis Sci. 2003;44(4):1753-9.

18. Libby P. Inflammation in atherosclerosis. Nature 2002;420(6917):868-74.

19. Higgins GT, Wang JH, Dockery P, Cleary PE, Redmond HP. Induction of angiogenic cytokine expression in cultured RPE by ingestion of oxidized photoreceptor outer segments. Invest Ophthalmol Vis Sci. 2003;44(4):1775-82.

20. Holtkamp GM, De Vos AF, Peek R, Kijlsta A. Analysis of the secretion pattern of monocyte chemotactic protein-1 (MCP-1) and transforming growth factor-beta 2 (TGF-beta2) by human retinal pigment epithelial cells. Clin Exp Immunol. 1999;118(1):35-40.

21. Oh H, Takagi H, Takagi C, Suzuma K, Otani A, Ishida K, et al. The Potencial Angiogenic Role of Macrophages in the Formation of Choroidal Neovascular Membranes. Invest Ophthalmol Vis Sci. 1999;40(9):1891-8.

22. Radisavljevic Z, Avraham H, Avraham S. Vascular endothelial growth factor up-regulates ICAM-1 expression via the phosphati-dylinositol 3 $\mathrm{OH}$-kinase/AKT/nitric oxide pathway and modulates migration of brain microvascular endothelial cells. J Biol Chem 2000;275(27):20770-4.

23. Joussen AM, Poulaki V, Qin W, Kirchhof B, Mitsiades N, Wiegand SJ, et al. Retinal vascular endothelial growth factor induces intercellular adhesion molecule-1 and endothelial nitric oxide synthase expression and initiates early diabetic retinal leukocytes adhesion in vivo. Am J Pathol. 2002;160(2):501-9.

24. Lutty G, Grunwald J, Majji AB, Uyama M, Yoneya S. Changes in choriocapillaris and retinal pigment epithelium in age-related macular degeneration. Mol Vis. 1999;5:35.

25. Korte GE, Reppucci V, Henkind P. RPE destruction causes choriocapillary atrophy. Invest Ophthalmol Vis Sci. 1984;25(10):1135-45.

26. Korte GE, Gerszberg T, Pua F, Henkind P. Choriocapillaris atrophy after experimental destruction of the retinal pigment epithelium in the rat: a study in thin section and vascular casts. Acta Anat (Basel). 1986;127(3):171-5.

27. Mammadzada P, Corredoira PM, André H. The role of hypoxia-inducible factors in neovascular age-related macular degeneration: a gene therapy perspective. Cell Mol Life Sci. 2020;77(5):819-33.
28. Shweiki D, Itin A, Soffer D, Keshet E. Vascular endothelial growth factor induced by hypoxia may mediate hypoxia-initiated angiogenesis. Nature. 1992;359(6398):843-5.

29. Kersten E, Paun CC, Schellevis RL, Hoyng CB, Delcourt C, Lengyel I, et al. Systemic and ocular fluid compounds as potential biomarkers in agerelated macular degeneration. Surv Ophthalmol. 2018;63(1):9-39.

30. van Leeuwen R, Boekhoorn S, Vingerling JR, Witteman JC, Klaver CC, Hofman $A$, et al. Dietary intake of antioxidants and risk of age-related macular degeneration. JAMA. 2005;294(24):3101-7.

31. Dinu M, Pagliai G, Casini A, Sofi F. Food groups and risk of age-related macular degeneration: a systematic review with meta-analysis. Eur J Nutr. 2019;58(5):2123-43.

32. McGuinness MB, Le J, Mitchell P, Gopinath B, Cerin E, Saksens NTM et al. Physical Activity and Age-related Macular Degeneration: A Systematic Literature Review and Meta-analysis. Am J Ophthalmol. 2017;180:29-38.

33. Cruickshanks KJ, Klein R, Klein BE. Sunlight and age-related macular degeneration. The Beaver Dam Eye Study. Arch Ophthalmol. 1993;111(4):514-8.

34. Ivanov IV, Mappes T, Schaupp P, Lappe C, Wahl S. Ultraviolet radiation oxidative stress affects eye health. J Biophotonics. 2018;11(7):e201700377.

35. Lv X, Li W, Fang Z, Xue X, Pan C. Periodontal disease and age related macular degeneration: a meta-analysis of 112,240 participants. BioMed Research International. 2020;2020: Article ID 4753645

36. Klein R, Lee KE, Gangnon RE, Klein BE. Relation of smoking, drinking, and physical activity to changes in vision over a 20-year period: the Beaver Dam Eye Study. Ophthalmology. 2014;121(6):1220-8.

37. World Health Organization (WHO). WHO global report on trends in prevalence of tobacco smoking 2000-2025. 2nd ed. Genève: WHO; 2018.

38. Evans JR, Lawrenson JG. A review of the evidence for dietary interventions in preventing or slowing the progression of age-related macular degeneration. Ophthalmic Physiol Opt. 2014;34(4):390-6.

39. Age-Related Eye Disease Study 2 Research Group. Lutein + zeaxanthin and omega-3 fatty acids for age-related macular degeneration: the AgeRelated Eye Disease Study 2 (AREDS2) randomized clinical trial. JAMA. 2013;309(19):2005-15

40. Apellis Pharmaceuticals Inc. Study of APL-2 Therapy in Patients Geographic Atrophy. (2017). [cited 2018 Nov 18]. Available from: https://ClinicalTrials. gov/show/ NCT02503332

41. Schwartz SD, Regillo CD, Lam BL, Eliott D, Rosenfeld PJ, Gregori NZ, et al. Human embryonic stem cell-derived retinal pigment epithelium in patients with age-related macular degeneration and Stargardt's macular dystrophy: follow-up of two open-label phase 1/2 studies. Lancet. 2015;385(9967):509-16.

42. da Cruz L, Fynes K, Georgiadis O, Kerby J, Luo YH, Ahmado A, et al. Phase 1 clinical study of an embryonic stem cell-derived retinal pigment epithelium patch in age-related macular degeneration. Nat Biotechnol. 2018;36(4):328-37.

43. Solomon SD, Lindsley K, Vedula SS, Krzystolik MG, Hawkins BS. Antivascular endothelial growth factor for neovascular age-related macular degeneration. Cochrane Database Syst Rev. 2014;(8):CD005139.

44. The Lancet. Age-related macular degeneration: treatment at what cost? Lancet. 2018;392(10153):1090.

45. Joondeph BC. Is Macular Degeneration slowly going away? Retina Today. 2018; May-June:42-6.

46. Park DH, Connor KM, Lambris JD. The challenges and promise of complement therapeutics for ocular diseases. Front Immunol. 2019;10:1007

47. Kauppinen A, Paterno JJ, Blasiak J, Salminen A, Kaarniranta K. Inflammation and its role in age-related macular degeneration. Cell Mol Life Sci. 2016;73(9):1765-86.

48. Wu J, Sun X. Complement system and age-related macular degeneration: drugs and challenges. Drug Des Devel Ther. 2019;13:2413-25. 